\title{
The Nitrogen-Assisted Triphenylphosphine Displacement of 3-Hydroxypyridine and 3-Aminopyridine Ligands in Palladium(II) Complexes: Crystal Structures of $\left[\mathrm{Pd}\left(\mathrm{PPh}_{3}\right) \mathrm{Br}\right]_{2}\left\{\mu, \eta^{2}-\mathrm{C}_{5} \mathrm{H}_{3} \mathrm{~N}(\mathrm{OH})\right\}_{2}$ and $\left[\mathrm{Pd}\left(\mathrm{PPh}_{3}\right) \mathrm{Br}\right]_{2}\left\{\mu, \eta^{2}-\mathrm{C}_{5} \mathrm{H}_{3} \mathrm{~N}\left(\mathrm{NH}_{2}\right)\right\}_{2}$
}

\author{
Kuang-Hway Yih ${ }^{\mathrm{a}} *$ ( 易光輝), Hsiao-Fen Wang ( 王曉芬), Keh-Feng Huang ${ }^{\mathrm{b}}$ ( 黃克峰 ), \\ Chang-Chi Kwan ${ }^{b}$ ( 官常慶) and Gene-Hsiang Lee ( 李錦祥) \\ ${ }^{a}$ Department of Applied Cosmetology, Hungkuang University Shalu, Taichung 433, Taiwan, R.O.C. \\ ${ }^{\mathrm{b}}$ Department of Applied Cosmetology, Providence University Shalu, Taichung 433, Taiwan, R.O.C. \\ ${ }^{\mathrm{c}}$ Instrumentation Center, College of Science, National Taiwan University, Taipei 106, Taiwan, R.O.C.
}

\begin{abstract}
Treatment of $\mathrm{Pd}\left(\mathrm{PPh}_{3}\right)_{4}$ with 2-bromo-3-hydroxypyridine $\left[\mathrm{C}_{5} \mathrm{H}_{3} \mathrm{~N}(\mathrm{OH}) \mathrm{Br}\right]$ and 3-amino-2-bromopyridine $\left[\mathrm{C}_{5} \mathrm{H}_{3} \mathrm{~N}\left(\mathrm{NH}_{2}\right) \mathrm{Br}\right]$ in dichloromethane at ambient temperature cause the oxidative addition reaction to produce the palladium complex $\left[\mathrm{Pd}\left(\mathrm{PPh}_{3}\right)_{2}\left\{\eta^{1}-\mathrm{C}_{5} \mathrm{H}_{3} \mathrm{~N}(\mathrm{OH})\right\}(\mathrm{Br})\right], 2$ and $\left[\mathrm{Pd}\left(\mathrm{PPh}_{3}\right)_{2}\left\{\eta^{1}-\right.\right.$ $\left.\left.\mathrm{C}_{5} \mathrm{H}_{3} \mathrm{~N}\left(\mathrm{NH}_{2}\right)\right\}(\mathrm{Br})\right], \mathbf{3}$, by substituting two triphenylphosphine ligands, respectively. In dichloromethane solution of complexes $\mathbf{2}$ and $\mathbf{3}$ at ambient temperature for $\mathbf{3}$ days, it undergo displacement of the triphenylphosphine ligand to form the dipalladium complexes $\left[\mathrm{Pd}\left(\mathrm{PPh}_{3}\right) \mathrm{Br}\right]_{2}\left\{\mu, \eta^{2}-\mathrm{C}_{5} \mathrm{H}_{3} \mathrm{~N}(\mathrm{OH})\right\}_{2}, 4$ and $\left[\mathrm{Pd}\left(\mathrm{PPh}_{3}\right) \mathrm{Br}\right]_{2}\left\{\mu, \eta^{2}-\mathrm{C}_{5} \mathrm{H}_{3} \mathrm{~N}\left(\mathrm{NH}_{2}\right)\right\}_{2}, \mathbf{5}$, in which the two 3-hydroxypyridine and 3-aminopyridine ligands coordinated through carbon to one metal center and bridging the other metal through nitrogen atom, respectively. Complexes $\mathbf{4}$ and $\mathbf{5}$ are characterized by X-ray diffraction analyses.
\end{abstract}

Keywords: 2-Bromo-3-hydroxypyridine; 3-Amino-2-bromopyridine; Palladium; Dipalladium; Nitrogen-assisted; X-ray diffraction.

\section{INTRODUCTION}

Palladium complexes catalyzed forming $\mathrm{C}-\mathrm{C}$ bond process are the most important reactions in organic synthesis. ${ }^{1}$ Intramolecular reductive elimination of Pd-N binuclear complex ${ }^{2}\left[\operatorname{Pd}\left(\mu-\mathrm{C}_{9} \mathrm{H}_{6} \mathrm{~N}\right)(\mu \text {-dppm })\right]_{2}(\mathrm{Cl})_{2}$ yielding organic compound 2,2'-biquinoline and complex $\left[\mathrm{Pd}_{2} \mathrm{Cl}_{2}-\right.$ $(\mathrm{dppm})_{2}$ ] has been reported. A. Beeby ${ }^{3}$ reported a pyridylbridged palladium complex as an effective precatalyst for the Suzuki cross-coupling reactions of a variety organoboronic acids and aryl bromides. The catalytic activity of dipalladium complex $\left[\mathrm{PdBr}_{2}\left(\mathrm{Bh}_{2} \text {-bimy }\right)\right]_{2}$ in aqueous SuzukiMiyaura cross-coupling reactions were studied by Huynh. ${ }^{4}$ The palladacycle complex $\left\{\mathrm{Pd}\left[\mathrm{P}\left(\mathrm{o}-\mathrm{C}_{6} \mathrm{H}_{4} \mathrm{CH}_{2}\right) \mathrm{Ph}_{2}\right]\right\}_{2}(\mu-$ $\mathrm{OAc})_{2}$ is a high efficient catalyst precursor for the coupling of aryl boronic acids and aryl halides. Complex $\left[\left(\mathrm{LPdCl}_{2}\right)_{2}\right]^{6}$ ( $\mathrm{L}=N, N^{\prime}$-bis(2,2-diethoxyethyl)imidazolium) exhibited excellent catalytic activity in Heck reaction.

Recently we reported syntheses, reactivities, interand intramolecular dissociation, and crystal structures of Pd complexes containing thiocarbamoyl, ${ }^{7}$ oxythiocarbon- $\mathrm{yl},{ }^{8}$ thiazolinyl, ${ }^{9}$ and methylpyridine ${ }^{10}$ moieties. These ligands induced forming binuclear complexes in which those were assisted by nitrogen or sulfur atom.

In order to obtain a better understanding of how these ligands interact with the metal center and the following study for applying in organic synthesis, we report the synthesis and crystal structures of dipalladium complexes including the 3-hydroxypyridine and 3-aminopyridine containing ligands in this paper.

\section{RESULTS AND DISCUSSION}

Treatment of $\mathrm{Pd}\left(\mathrm{PPh}_{3}\right)_{4}$, 1 with 2-bromo-3-hydroxypyridine $\left[\mathrm{C}_{5} \mathrm{H}_{3} \mathrm{~N}(\mathrm{OH}) \mathrm{Br}\right]$ and 3-amino-2-bromopyridine $\left[\mathrm{C}_{5} \mathrm{H}_{3} \mathrm{~N}\left(\mathrm{NH}_{2}\right) \mathrm{Br}\right]$, in dichloromethane at ambient temperature yield the colorless complexes $\left[\mathrm{Pd}\left(\mathrm{PPh}_{3}\right)_{2}\left\{\eta^{1}-\mathrm{C}_{5} \mathrm{H}_{3} \mathrm{~N}\right.\right.$ $(\mathrm{OH})\}(\mathrm{Br})], 2$ and $\left[\mathrm{Pd}\left(\mathrm{PPh}_{3}\right)_{2}\left\{\eta^{1}-\mathrm{C}_{5} \mathrm{H}_{3} \mathrm{~N}\left(\mathrm{NH}_{2}\right)\right\}(\mathrm{Br})\right], \mathbf{3}$, with 92 and $91 \%$ isolated yield, respectively (Scheme I). The air-stable colorless compounds $\mathbf{2}$ and $\mathbf{3}$ are soluble in dichloromethane and acetonitrile, slightly soluble in methanol, and insoluble in diethyl ether and $n$-hexane. By con-

\footnotetext{
* Corresponding author. E-mail: khyih@sunrise.hk.edu.tw
} 


\section{Scheme I}

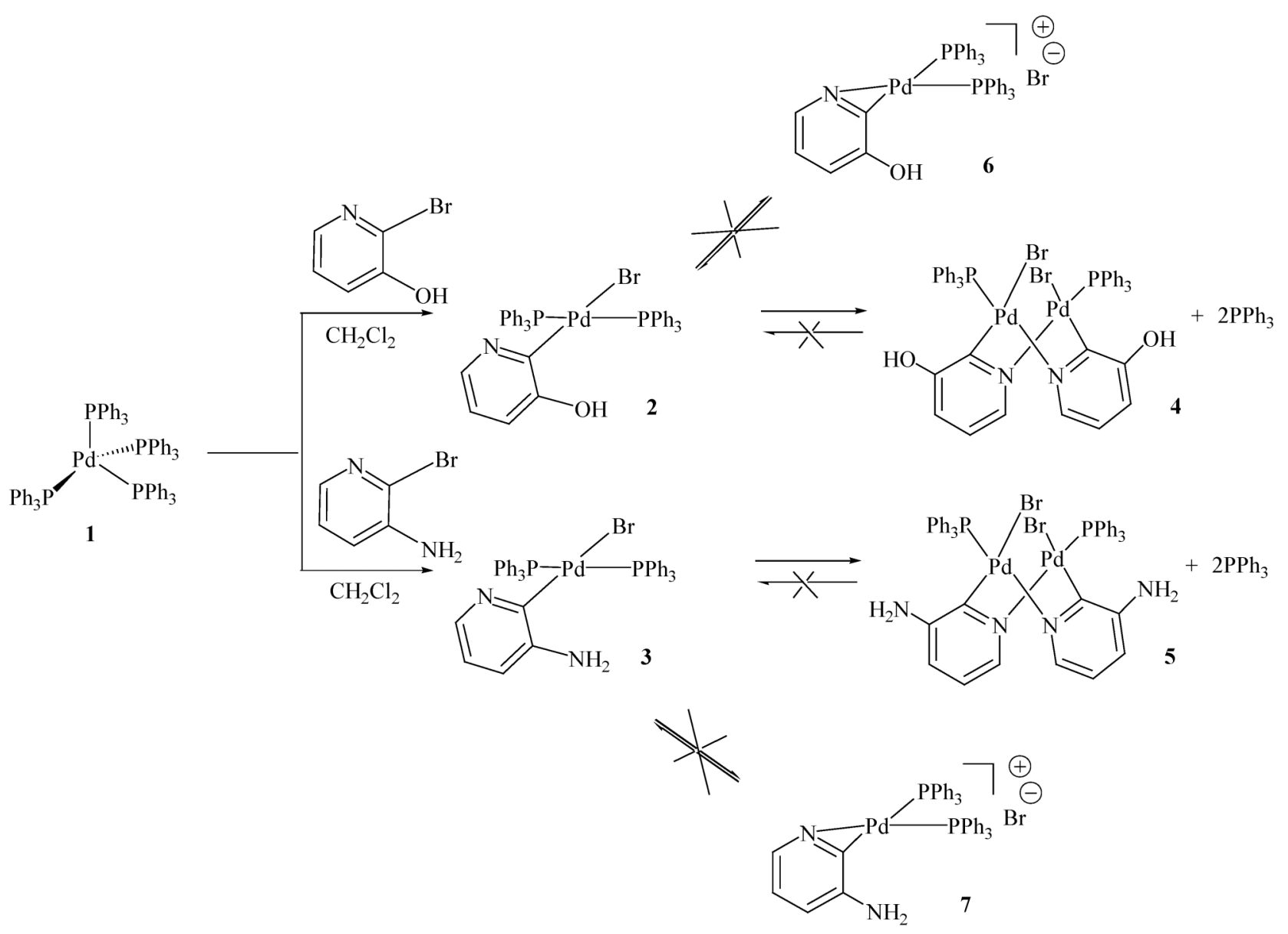

tinuous stirring the dichloromethane solution of complexes $\mathbf{2}$ and $\mathbf{3}$ at ambient temperature for $\mathbf{3}$ days, the displacement of triphenylphosphine by nitrogen atom from the other 3-hydroxypyridine-metal and 3-aminopyridinemetal complexes yielded the air-stable colorless dipalladium complexes $\left[\mathrm{Pd}\left(\mathrm{PPh}_{3}\right) \mathrm{Br}\right]_{2}\left\{\mu, \eta^{2}-\mathrm{C}_{5} \mathrm{H}_{3} \mathrm{~N}(\mathrm{OH})\right\}_{2}, 4$ and $\left[\mathrm{Pd}\left(\mathrm{PPh}_{3}\right) \mathrm{Br}\right]_{2}\left\{\mu, \eta^{2}-\mathrm{C}_{5} \mathrm{H}_{3} \mathrm{~N}\left(\mathrm{NH}_{2}\right)\right\}_{2}, 5$ with 93 and $94 \%$ isolated yield, respectively. The air-stable colorless compounds $\mathbf{4}$ and $\mathbf{5}$ are also soluble in dichloromethane and acetonitrile, slightly soluble in methanol, and insoluble in diethyl ether and $n$-hexane.

The spectroscopic and analytical data of $\mathbf{2}$ and $\mathbf{3}$ are in good agreement with the formulation. The FAB mass spectra of $\mathbf{2}$ and $\mathbf{3}$ show parent peaks with the typical Pd isotope distribution corresponding to $\left[\mathrm{M}^{+}\right]$molecular mass, respectively. The ${ }^{31} \mathrm{P}\left\{{ }^{1} \mathrm{H}\right\}$ and ${ }^{1} \mathrm{H}$ NMR spectra of $\mathbf{2}$ and $\mathbf{3}$ are similar. The ${ }^{31} \mathrm{P}\left\{{ }^{1} \mathrm{H}\right\}$ NMR spectra of $\mathbf{2}$ and $\mathbf{3}$ show a singlet resonances at $\delta 22.1$ and $\delta 23.1$, respectively. In the ${ }^{1} \mathrm{H}$ NMR spectra, the $5-\mathrm{H}$ and $4-\mathrm{H}$ protons of the pyridine groups exhibit one doublet and one broad resonance at $\delta$ $5.87(6.5 \mathrm{~Hz})$ and $\delta 6.08$ for 2 and at $\delta 5.60(6.5 \mathrm{~Hz})$ and $\delta$ 5.94 for 3. The ${ }^{13} \mathrm{C}\left\{{ }^{1} \mathrm{H}\right\}$ NMR spectra of $\mathbf{2}$ and $\mathbf{3}$ reveal two singlet at up field, which are assigned to the 5-C and 4-C carbon atom of the pyridine group $(\delta 117.3,119.7$ and $\delta$ $116.6,117.6)$. It is clear those oxidative additions of 2 -bromo-3-hydroxypyridine and 3-amino-2-bromopyridine to the starting complex 1 with releasing two $\mathrm{PPh}_{3}$ molecules were observed respectively. In complexes $\mathbf{2}$ and 3, two $\mathrm{PPh}_{3}$ molecules and the 3-hydroxypyridine and bromide and two $\mathrm{PPh}_{3}$ molecules and the 3-aminopyridine and bromide are in the trans position, respectively, and the 3-hydroxypyridine and 3-aminopyridine ligands coordinated to the palladium metal through the carbon atom, respectively.

The FAB mass spectra of $\mathbf{4}$ and $\mathbf{5}$ show parent peaks with the typical $\mathrm{Pd}$ isotope distribution corresponding to $\left[\mathrm{M}^{+}\right]$molecular mass, respectively. The ${ }^{31} \mathrm{P}\left\{{ }^{1} \mathrm{H}\right\}$ NMR spectra of $\mathbf{4}$ and $\mathbf{5}$ show a singlet resonances at $\delta 27.9$ and $\delta$ 27.3, respectively. In the ${ }^{1} \mathrm{H}$ NMR spectra, the 5-H and 4-H 
protons of the pyridine groups exhibit one doublet and one triplet resonance at $\delta 5.94(8.0 \mathrm{~Hz})$ and $\delta 6.38(6.1 \mathrm{~Hz})$ for 4 and at $\delta 5.66(6.5 \mathrm{~Hz})$ and $\delta 6.25(7.5 \mathrm{~Hz})$ for 5. The ${ }^{13} \mathrm{C}\left\{{ }^{1} \mathrm{H}\right\}$ NMR spectra of $\mathbf{4}$ and $\mathbf{5}$ reveal two singlet at up field, which are assigned to the 5-C and 4-C carbon atom of the pyridine group $(\delta 123.2,124.2$ and $\delta 121.9,123.6)$. In complexes $\mathbf{4}$ and $\mathbf{5}$, the NMR data suggest that palladation occurs at the 3-hydroxypyridine and 3-aminopyridine rings and EA suggest that complexes $\mathbf{4}$ and $\mathbf{5}$ contain only one phosphine ligand per metal atom.

The variable low-temperature ${ }^{1} \mathrm{H}$ or ${ }^{31} \mathrm{P}\left\{{ }^{1} \mathrm{H}\right\}$ NMR spectra of $\mathbf{2}$ and $\mathbf{3}$ do not show another sets of proton resonances of 3-hydroxypyridine, 3-aminopyridine or triphenylphosphine resonances from 298 to $223 \mathrm{~K}$ in $\mathrm{CDCl}_{3}$. Within the temperature range, no doublet resonances were observed in the ${ }^{31} \mathrm{P}\left\{{ }^{1} \mathrm{H}\right\}$ NMR spectra. One can conclude that no intramolecular bromide displacement product $\left[\mathrm{Pd}\left(\mathrm{PPh}_{3}\right)_{2}\left\{\eta^{2}-\mathrm{C}_{5} \mathrm{H}_{3} \mathrm{~N}(\mathrm{OH})\right\}\right][\mathrm{Br}], 6$ or $\left[\mathrm{Pd}\left(\mathrm{PPh}_{3}\right)_{2}\left\{\eta^{2}-\right.\right.$
$\left.\left.\mathrm{C}_{5} \mathrm{H}_{3} \mathrm{~N}\left(\mathrm{NH}_{2}\right)\right\}\right][\mathrm{Br}], 7$ was found. The phenomenon is different to that of thiazoline $\mathrm{Pd}$ complex $\left[\mathrm{Pd}\left(\mathrm{PPh}_{3}\right)_{2}\left(\eta^{1}-\right.\right.$ $\mathrm{CSCHCHN})(\mathrm{Br})] .{ }^{9}$ In the thiocarbamoyl Pd example, complex $\left[\mathrm{Pd}\left(\mathrm{PPh}_{3}\right)_{2}\left(\eta^{1}-\mathrm{SCNMe}_{2}\right)(\mathrm{Cl})\right]$, showing the inter- and intramolecular dissociation behavior, was shown to form complexes $\left[\mathrm{Pd}\left(\mathrm{PPh}_{3}\right) \mathrm{Cl}\right]_{2}\left(\mu, \eta^{2}-\mathrm{SCNMe}_{2}\right)_{2}$ and $[\mathrm{Pd}-$ $\left.\left(\mathrm{PPh}_{3}\right)_{2}\left(\eta^{2}-\mathrm{SCNMe}_{2}\right)\right][\mathrm{Cl}]^{7 \mathrm{a}}$

The variable high-temperature ${ }^{1} \mathrm{H}$ and ${ }^{31} \mathrm{P}\left\{{ }^{1} \mathrm{H}\right\}$ NMR spectra of 3 show another sets of proton resonances of 3aminopyridine and triphenylphosphine resonances from 298 to $348 \mathrm{~K}$ in $\mathrm{CDCl}_{3}$ (Fig. 1).

In order to obtain a definitive assignment, X-ray single-crystals diffraction studies were carried out on complexes $\mathbf{4}$ and 5. Single crystals of complexes $\mathbf{4}$ and $\mathbf{5}$ were grown by slow diffusion of $n$-hexane into a dichloromethane solution at $4{ }^{\circ} \mathrm{C}$. ORTEP plots of $\mathbf{4}$ and $\mathbf{5}$ are shown in Figs. 2 and 3. Table 1 contains crystal data and refinement details and selected bond distances and angles of $\mathbf{4}$ and $\mathbf{5}$. In

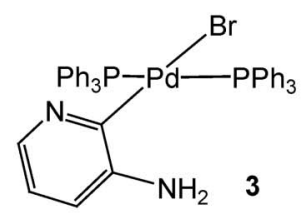

(a)

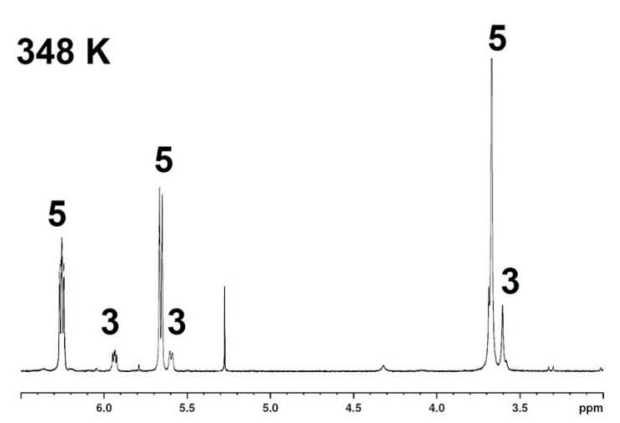

298 K

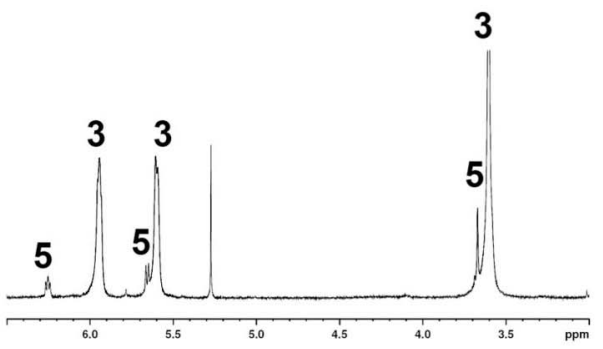

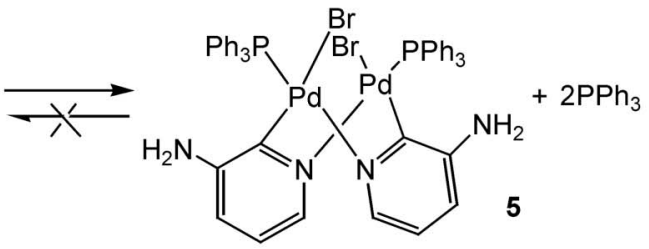

(b)

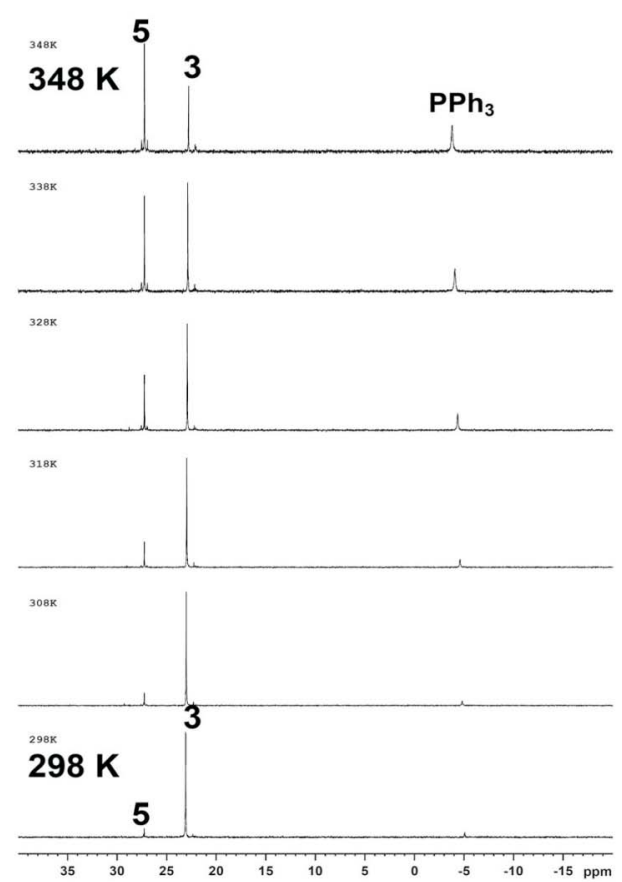

Fig. 1. Variable temperature (a) ${ }^{1} \mathrm{H}$ and (b) ${ }^{31} \mathrm{P}\left\{{ }^{1} \mathrm{H}\right\}$ NMR spectra of complexes $\left[\mathrm{Pd}\left(\mathrm{PPh}_{3}\right)_{2}\left\{\eta^{1}-\mathrm{C}_{5} \mathrm{H}_{3} \mathrm{~N}(\mathrm{NH})\right\}(\mathrm{Br})\right], 3$ from $298 \mathrm{~K}$ to $348 \mathrm{~K}$ in $\mathrm{CDCl}_{3}$. 
complexes $\mathbf{4}$ and $\mathbf{5}$, the 3-hydroxypyridine and 3-aminopyridine ligands are $\sigma$-bonded to $\mathrm{Pd}$ atom through the carbon atom, respectively. Complexes $\mathbf{4}$ and $\mathbf{5}$ are dimer with each 3-hydroxypyridine and 3-aminopyridine units bridging through carbon atom of 3-hydroxypyridine and 3-aminopyridine groups to one metal center and nitrogen atom to the other metal forming a six-membered ring with boatform geometry. The Pd-Pd bond distance of 3.1823(9) $\AA$ in 4 and 3.1925(5) $\AA$ in 5 indicate no bonding interaction between the Pd metal atoms. It is clear that the 3-hydroxypyridine and 3-aminopyridine nitrogen atoms are preferentially bonded and that the triphenylphosphine ligands favor the trans site to the nitrogen donors, which have a lower trans influence.

Within the 3-hydroxypyridine and 3-aminopyridine ligands themselves, the geometries are consistent with significant partial double bond character in the pyridine ring. Thus, the $\mathrm{C}(1)-\mathrm{C}(2)$ and $\mathrm{C}(6)-\mathrm{C}(7)$ bond distances (1.388(12) $\AA, 1.392(12) \AA$ of $\mathbf{4}$ and 1.413(6) $\AA, 1.408(6) \AA$ of 5) are comparable to the C-C double bond (1.34 $\AA$ ).

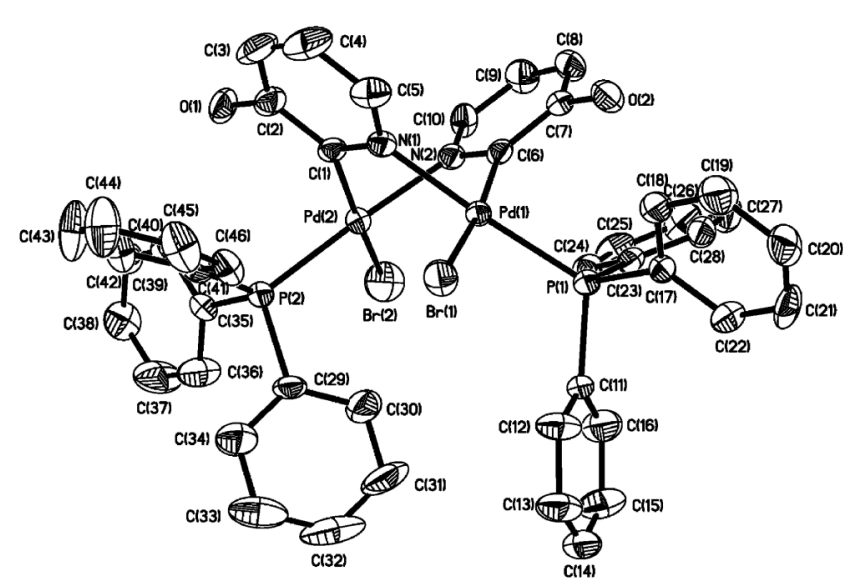

Fig. 2. An ORTEP drawing with 50\% thermal ellipsoids and atom-numbering scheme for the complex $\left[\mathrm{Pd}\left(\mathrm{PPh}_{3}\right) \mathrm{Br}\right]_{2}\left\{\mu, \eta^{2}-\mathrm{C}_{5} \mathrm{H}_{3} \mathrm{~N}(\mathrm{OH})\right\}_{2}, 4$. Selected bond distances $(\AA)$ and angles $\left(^{\circ}\right)$ are as follows: $\operatorname{Pd}(1)-\mathrm{C}(6)$ 1.997(8), $\quad \mathrm{Pd}(1)-\mathrm{N}(1)$ 2.082(7), $\mathrm{Pd}(1)-\mathrm{P}(1)$ 2.283(2), $\mathrm{Pd}(1)-\mathrm{Br}(1)$ 2.5160(11), $\mathrm{Pd}(2)-\mathrm{C}(1) 1.992(8), \operatorname{Pd}(2)-\mathrm{N}(2)$ 2.092(7), $\mathrm{Pd}(2)-\mathrm{P}(2) \quad 2.258(2), \operatorname{Pd}(2)-\mathrm{Br}(2)$ 2.513(2), C(6)-Pd(1)-N(1) 83.8(3), C(6)-Pd(1)$\mathrm{P}(1)$ 91.02(2), N(1)-Pd(1)-Br(1) 88.88(19), $\mathrm{P}(1)-\mathrm{Pd}(1)-\mathrm{Br}(1)$ 96.24(6), C(1)-Pd(2)-N(2) 85.5(3), C(1)-Pd(2)-P(2) 92.5(2), N(2)-Pd(2)$\mathrm{Br}(2) \quad 89.8(2), \quad \mathrm{P}(2)-\mathrm{Pd}(2)-\mathrm{Br}(2)$ 93.11(8), $\mathrm{C}(1)-\mathrm{N}(1)-\mathrm{Pd}(1) \quad 117.0(6), \mathrm{C}(6)-\mathrm{N}(2)-\mathrm{Pd}(2)$ 116.2(5), N(1)-C(1)-Pd(2) 116.3(6), N(2)-C(6)$\operatorname{Pd}(1)$ 117.3(6).
The PdC-N bond distances (1.346(11) $\AA$ (av) of 4 and 1.333(6) $\AA$ (av) of 5) are typical for a C-N bond having partial double bond character and are certainly much shorter than the normal C-N (1.47 $\AA$ ) single bond. The average

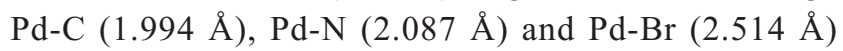
lengths for 4 and average Pd-C (1.999 $\AA), \operatorname{Pd}-\mathrm{N}(2.082 \AA)$ and $\mathrm{Pd}-\mathrm{Br}(2.495 \AA$ ) lengths for 5 are in agreement with reported value. ${ }^{11}$ In complexes $\mathbf{4}$ and $\mathbf{5}$, each palladium atom exhibits a square-planar geometry with the bromide and carbon bonds in a trans configuration. The Pd-Pd interatomic distances are 3.1823(9) $\AA$ and 3.1925(5) $\AA$ and is consistent with the structure reported ${ }^{12}$ (3.194(2) $\AA$ ) and the chlorine analogue ${ }^{13}(3.165(3) \AA)$, previously published. Reactions of $\mathbf{2}$ and $\mathbf{3}$ with nucleophiles for finding different bonding modes and applying complexes $\mathbf{4}$ and $\mathbf{5}$ in organic synthesis are currently under investigation.

We employ oxidative addition reaction of 2-bromo3-hydroxypyridine and 3-amino-2-bromopyridine to palladium complexes to investigate the bonding modes of 3-hy-

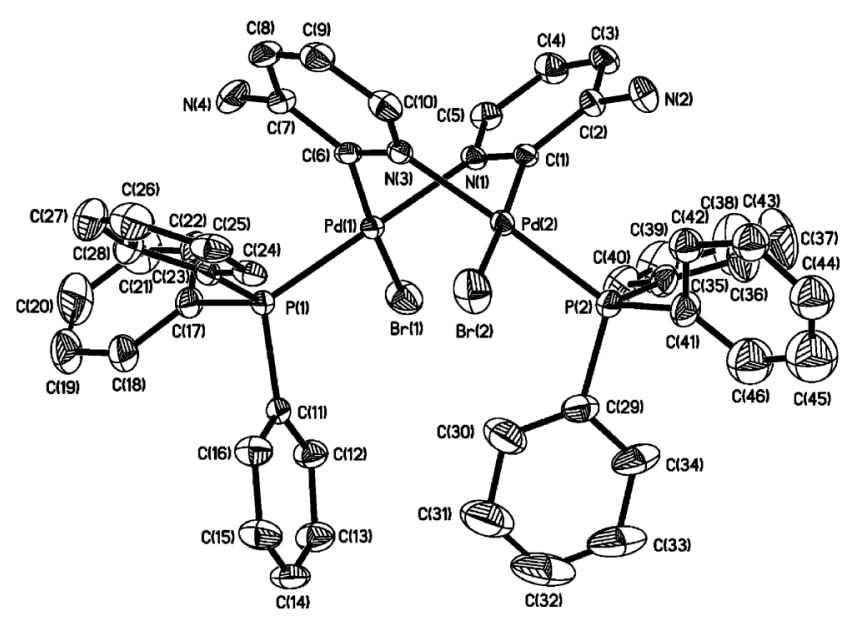

Fig. 3. An ORTEP drawing with 50\% thermal ellipsoids and atom-numbering scheme for the complex $\left[\mathrm{Pd}\left(\mathrm{PPh}_{3}\right) \mathrm{Br}\right]_{2}\left\{\mu, \eta^{2}-\mathrm{C}_{5} \mathrm{H}_{3} \mathrm{~N}\left(\mathrm{NH}_{2}\right)\right\}_{2}, \mathbf{5}$. Selected bond distances $(\AA)$ and angles $\left({ }^{\circ}\right)$ are as follows: $\operatorname{Pd}(1)-\mathrm{C}(6) 2.006(4), \operatorname{Pd}(1)-\mathrm{N}(1)$ 2.084(4), $\mathrm{Pd}(1)-\mathrm{P}(1) 2.2771(11), \operatorname{Pd}(1)-\mathrm{Br}(1)$ 2.5019(6), $\mathrm{Pd}(2)-\mathrm{C}(1)$ 1.992(4), $\mathrm{Pd}(2)-\mathrm{N}(3)$ 2.081(4), $\mathrm{Pd}(2)-\mathrm{P}(2)$ 2.2682(12), $\mathrm{Pd}(2)-\mathrm{Br}(2)$ 2.4877(7), C(6)-Pd(1)-N(1) 85.02(16), C(6)$\mathrm{Pd}(1)-\mathrm{P}(1)$ 91.00(13), N(1)-Pd(1)-Br(1) 89.20(10), $\mathrm{P}(1)-\mathrm{Pd}(1)-\mathrm{Br}(1)$ 95.17(3), C(1)-Pd(2)-N(3) 85.55(16), C(1)-Pd(2)-P(2) 91.24(13), N(3)$\operatorname{Pd}(2)-\operatorname{Br}(2) \quad 90.11(10), \quad \mathrm{P}(2)-\operatorname{Pd}(2)-\operatorname{Br}(2)$ 93.69(4), C(1)-N(1)-Pd(1) 116.6(3), C(6)$\mathrm{N}(3)-\mathrm{Pd}(2)$ 116.6(3), N(1)-C(1)-Pd(2) 117.5(3), $\mathrm{N}(3)-\mathrm{C}(6)-\mathrm{Pd}(1)$ 117.5(3). 
Table 1. Crystal data and refinement details for complexes $\mathbf{4} \cdot \mathrm{CH}_{2} \mathrm{Cl}_{2}+1 / 2 \mathrm{Ether}+\mathrm{H}_{2} \mathrm{O}$ and 5 $2 \mathrm{CH}_{2} \mathrm{Cl}_{2}$

\begin{tabular}{|c|c|c|}
\hline & $4 \cdot \mathrm{CH}_{2} \mathrm{Cl}_{2}+1 / 2$ Ether $+\mathrm{H}_{2} \mathrm{O}$ & $5 \cdot 2 \mathrm{CH}_{2} \mathrm{Cl}_{2}$ \\
\hline Chemical formula & $\mathrm{C}_{49} \mathrm{H}_{45} \mathrm{Br}_{2} \mathrm{Cl}_{2} \mathrm{~N}_{2} \mathrm{O}_{3.5} \mathrm{P}_{2} \mathrm{Pd}_{2}$ & $\mathrm{C}_{48} \mathrm{H}_{44} \mathrm{Br}_{2} \mathrm{Cl}_{4} \mathrm{~N}_{4} \mathrm{P}_{2} \mathrm{Pd}_{2}$ \\
\hline Formula weight & 1223.33 & 1253.23 \\
\hline Crystal system & triclinic & triclinic \\
\hline Space group & $\mathrm{P} \overline{1}$ & $\mathrm{P} \overline{1}$ \\
\hline$a, \AA$ & $13.2636(10)$ & $10.2792(5)$ \\
\hline$b, \AA$ & $13.5407(10)$ & $14.0223(7)$ \\
\hline$c, \AA$ & $16.2284(12)$ & $18.7322(10)$ \\
\hline$\alpha, \operatorname{deg}$ & $69.899(2)$ & $73.854(1)$ \\
\hline$\beta, \operatorname{deg}$ & $74.327(2)$ & $74.982(1)$ \\
\hline$\gamma, \operatorname{deg}$ & $76.828(2)$ & $72.659(1)$ \\
\hline $\mathrm{V}, \AA^{3}$ & $2605.7(3)$ & $2429.5(2)$ \\
\hline Z & 2 & 2 \\
\hline$\rho_{\text {calcd }}, \mathrm{g} \mathrm{cm}^{-3}$ & 1.559 & 1.713 \\
\hline$\mu,(\mathrm{Mo} \mathrm{K} \alpha), \mathrm{mm}^{-1}$ & 2.429 & 2.709 \\
\hline$\lambda, \AA$ & 0.71073 & 0.71073 \\
\hline$T, \mathrm{~K}$ & $150(2)$ & $150(2)$ \\
\hline$\theta$ range, deg & $1.37-25.00$ & $1.15-27.50$ \\
\hline Independent rflns & 9173 & 11139 \\
\hline No. of variables & 541 & 579 \\
\hline $\mathrm{R}^{\mathrm{a}}$ & 0.072 & 0.049 \\
\hline $\mathrm{R}_{w}{ }^{\mathrm{b}}$ & 0.195 & 0.131 \\
\hline $\mathrm{S}^{\mathrm{c}}$ & 1.076 & 1.038 \\
\hline
\end{tabular}

droxypyridine and 3-aminopyridine. In complexes $\mathbf{4}$ and $\mathbf{5}$, the two 3-hydroxypyridine and 3-aminopyridine ligands coordinated through carbon to one metal center and bridging the other metal through nitrogen atom. The nitrogen atom of the 3-hydroxypyridine and 3-aminopyridine ligands assist intermolecular triphenylphosphine displacement of $\mathbf{2}$ and $\mathbf{3}$ to form $\mathbf{4}$ and $\mathbf{5}$.

\section{EXPERIMENTAL SECTION}

\section{General Procedures}

All manipulations were performed under nitrogen using vacuum-line and standard Schlenk techniques. NMR spectra were recorded on an AM-500 WB FT-NMR spectrometer and are reported in units of parts per million with residual protons in the solvent as an internal standard $\left(\mathrm{CDCl}_{3}, \delta\right.$ 7.24). ${ }^{31} \mathrm{P}\left\{{ }^{1} \mathrm{H}\right\}$ NMR spectra were referenced to $85 \% \mathrm{H}_{3} \mathrm{PO}_{4}$ external capillary. IR spectra were measured on a Nicolate Avator-320 instrument and referenced to polystyrene standard, using cells equipped with calcium fluoride windows. MS spectra were recorded on a JEOL SX-102A spectrometer. Solvents were dried and deoxy- genated by refluxing over the appropriate reagents before use. $n$-Hexane and diethyl ether were distilled from sodium-benzophenone. Acetonitrile and dichloromethane were distilled from calcium hydride, and methanol was distilled from magnesium. All other solvents and reagents were of reagent grade and used as received. Elemental analyses and X-ray diffraction studies were carried out at the Regional Center of Analytical Instrument located at the National Taiwan University. $\mathrm{PdCl}_{2}$ was purchased from Strem Chemical and 2-bromo-3-hydroxypyridine and 3amino-2-bromopyridine were purchased from Merck.

Preparation of $\left[\mathbf{P d}\left(\mathrm{PPh}_{3}\right)_{2}\left\{\eta^{1}-\mathrm{C}_{5} \mathbf{H}_{3} \mathbf{N}(\mathrm{OH})\right\}(\mathrm{Br})\right], 2$

2-Bromo-3-hydroxypyridine (0.209 g, $1.2 \mathrm{mmol})$ was added to a flask $(100 \mathrm{~mL})$ containing $\mathrm{Pd}\left(\mathrm{PPh}_{3}\right)_{4}(1.155$ g, $1.0 \mathrm{mmol})$ and $\mathrm{CH}_{2} \mathrm{Cl}_{2}(20 \mathrm{~mL})$ at ambient temperature. The mixture was stirred for about $2 \mathrm{~h}$. The solvent was concentrated to $10 \mathrm{~mL}$, and $20 \mathrm{~mL}$ of diethyl ether was added to the solution. The colorless solids were formed which were isolated by filtration (G4), washed with $n$-hexane $(2 \times 10$ $\mathrm{mL})$ and subsequently dried under vacuum yielding 0.741 g $(92 \%)$ of $\left[\mathrm{Pd}\left(\mathrm{PPh}_{3}\right)_{2}\left\{\eta^{1}-\mathrm{C}_{5} \mathrm{H}_{3} \mathrm{~N}(\mathrm{OH})\right\}(\mathrm{Br})\right], 2$. Spectro- 
scopic data for $2:{ }^{31} \mathrm{P}\left\{{ }^{1} \mathrm{H}\right\} \mathrm{NMR}: \delta 22.1\left(\mathrm{~s}, \mathrm{PPh}_{3}\right) .{ }^{1} \mathrm{H}$ NMR: $\delta 5.87\left(\mathrm{~d}, 1 \mathrm{H}, 5-\mathrm{H}\right.$ of pyridine, $\left.{ }^{2} J_{\mathrm{H}-\mathrm{H}}=6.5 \mathrm{~Hz}\right), 6.08(\mathrm{br}, 1 \mathrm{H}$, 4-H of pyridine), 7.11-7.62 (m, 31H, Ph, pyridine) ${ }^{13} \mathrm{C}\left\{{ }^{1} \mathrm{H}\right\}$ NMR: $\delta 117.3$ (s, 5-C of pyridine), 119.7 (s, 5-C of pyridine). MS (FAB, NBA, $m / z): 805\left[\mathrm{M}^{+}\right]$. Anal. Calcd. for $\mathrm{C}_{41} \mathrm{H}_{34} \mathrm{BrNOP} 2 \mathrm{Pd}$ : C, 61.17; H, 4.26; N, 1.74. Found: C, 61.25; H, 4.31; N, 1.64 .

\section{Preparation of $\left[\mathbf{P d}\left(\mathrm{PPh}_{3}\right)_{2}\left\{\eta^{1}-\mathrm{C}_{5} \mathrm{H}_{3} \mathbf{N}\left(\mathrm{NH}_{2}\right)\right\}(\mathrm{Br})\right], 3$}

3-Amino-2-bromopyridine $(0.260 \mathrm{~g}, 1.5 \mathrm{mmol})$ was added to a flask $(100 \mathrm{~mL})$ containing $\mathrm{Pd}\left(\mathrm{PPh}_{3}\right)_{4}(1.155 \mathrm{~g}$, $1.0 \mathrm{mmol})$ and $\mathrm{CH}_{2} \mathrm{Cl}_{2}(20 \mathrm{~mL})$ at ambient temperature. The mixture was stirred for about $3 \mathrm{~h}$. The solvent was concentrated to $10 \mathrm{~mL}$, and $20 \mathrm{~mL}$ of diethyl ether was added to the solution. The colorless solids were formed which were isolated by filtration (G4), washed with $n$-hexane $(2 \times 10$ $\mathrm{mL})$ and subsequently dried under vacuum yielding 0.734 $\mathrm{g}(91 \%)$ of $\left[\mathrm{Pd}\left(\mathrm{PPh}_{3}\right)_{2}\left\{\eta^{1}-\mathrm{C}_{5} \mathrm{H}_{3} \mathrm{~N}\left(\mathrm{NH}_{2}\right)\right\}(\mathrm{Br})\right], 3$. Spectroscopic data for 3: ${ }^{31} \mathrm{P}\left\{{ }^{1} \mathrm{H}\right\}$ NMR: $\delta 23.1\left(\mathrm{~s}, \mathrm{PPh}_{3}\right) .{ }^{1} \mathrm{H}$ NMR: $\delta 3.61\left(\mathrm{br}, 2 \mathrm{H}, \mathrm{NH}_{2}\right), 5.60\left(\mathrm{~d}, 1 \mathrm{H}, 5-\mathrm{H}\right.$ of pyridine, ${ }^{2} J_{\mathrm{H}-\mathrm{H}}=$ $6.5 \mathrm{~Hz}$ ), 5.94 (br, 1H, 4-H of pyridine), 7.11-7.62 (m, 31H, Ph, pyridine). ${ }^{13} \mathrm{C}\left\{{ }^{1} \mathrm{H}\right\}$ NMR: $\delta 116.6$ (s, 5-C of pyridine), 117.6 (s, 5-C of pyridine). MS (FAB, NBA, $m / z): 804\left[\mathrm{M}^{+}\right]$. Anal. Calcd. for $\mathrm{C}_{41} \mathrm{H}_{35} \mathrm{BrN}_{2} \mathrm{P}_{2} \mathrm{Pd}$ : C, 61.25; H, 4.39; N, 3.49. Found: C, 61.45; H, 4.50; N, 3.24.

Preparation of $\left[\mathrm{Pd}\left(\mathrm{PPh}_{3}\right) \mathrm{Br}\right]_{2}\left\{\mu, \eta^{2}-\mathrm{C}_{5} \mathrm{H}_{3} \mathrm{~N}(\mathrm{OH})\right\}_{2}, 4$

$\mathrm{CH}_{2} \mathrm{Cl}_{2}(20 \mathrm{~mL})$ was added to a flask $(100 \mathrm{~mL})$ containing $2(0.805 \mathrm{~g}, 1.0 \mathrm{mmol})$. The solution was stirred for 3 days then $n$-hexane $(30 \mathrm{~mL})$ was added to the solution and a colorless precipitate was formed. The precipitate was collected by filtration (G4) washed with $n$-hexane $(2 \times 10 \mathrm{~mL})$ and then dried in vacuo yielding $0.505 \mathrm{~g}(93 \%)$ of 4 . Spectroscopic data for 4: ${ }^{31} \mathrm{P}\left\{{ }^{1} \mathrm{H}\right\}$ NMR: $\delta 27.9\left(\mathrm{~s}, \mathrm{PPh}_{3}\right) .{ }^{1} \mathrm{H}$ NMR: $\delta 5.94\left(\mathrm{~d}, 2 \mathrm{H}, 5-\mathrm{H}\right.$ of pyridine, $\left.{ }^{2} J_{\mathrm{H}-\mathrm{H}}=8.0 \mathrm{~Hz}\right), 6.38$ $\left(\mathrm{t}, 2 \mathrm{H}, 4-\mathrm{H}\right.$ of pyridine, $\left.{ }^{2} J_{\mathrm{H}-\mathrm{H}}=6.1 \mathrm{~Hz}\right), 7.21-7.72(\mathrm{~m}, 32 \mathrm{H}$, Ph, pyridine). ${ }^{13} \mathrm{C}\left\{{ }^{1} \mathrm{H}\right\}$ NMR: $\delta 123.2$ (s, 5-C of pyridine), 124.2 (s, 4-C of pyridine). MS (FAB, NBA, $m / z$ ): 1085 $\left[\mathrm{M}^{+}\right]$. Anal. Calcd. for $\mathrm{C}_{46} \mathrm{H}_{38} \mathrm{Br}_{2} \mathrm{~N}_{2} \mathrm{O}_{2} \mathrm{P}_{2} \mathrm{Pd}_{2}$ : C, 50.90; $\mathrm{H}$, 3.53 ; N, 2.58. Found: C, 51.02; H, 3.62; N, 2.44.

Preparation of $\left[\mathrm{Pd}\left(\mathrm{PPh}_{3}\right) \mathrm{Br}\right]_{2}\left\{\mu, \eta^{2}-\mathrm{C}_{5} \mathrm{H}_{3} \mathrm{~N}\left(\mathrm{NH}_{2}\right)\right\}_{2}, 5$

$\mathrm{CH}_{2} \mathrm{Cl}_{2}(20 \mathrm{~mL})$ was added to a flask $(100 \mathrm{~mL})$ containing 3 ( $0.804 \mathrm{~g}, 1.0 \mathrm{mmol})$. The solution was stirred for 3 days then $n$-hexane $(30 \mathrm{~mL})$ was added to the solution and a colorless precipitate was formed. The precipitate was collected by filtration (G4) washed with $n$-hexane $(2 \times 10 \mathrm{~mL})$ and then dried in vacuo yielding $0.378 \mathrm{~g}(94 \%)$ of $\mathbf{5}$. Spectroscopic data for 5: ${ }^{31} \mathrm{P}\left\{{ }^{1} \mathrm{H}\right\}$ NMR: $\delta 27.3\left(\mathrm{~s}, \mathrm{PPh}_{3}\right) .{ }^{1} \mathrm{H}$ NMR: $\delta 3.67$ (br, 4H, $\mathrm{NH}_{2}$ ), $5.66(\mathrm{~d}, 2 \mathrm{H}, 5-\mathrm{H}$ of pyridine, $\left.{ }^{2} J_{\mathrm{H}-\mathrm{H}}=6.5 \mathrm{~Hz}\right), 6.25(\mathrm{t}, 2 \mathrm{H}, 4-\mathrm{H}$ of pyridine), 7.17-7.68 (m, $32 \mathrm{H}, \mathrm{Ph}$, pyridine). ${ }^{13} \mathrm{C}\left\{{ }^{1} \mathrm{H}\right\}$ NMR: $\delta 121.9$ (s, 5-C of pyridine), 123.6 (s, 4-C of pyridine). MS (FAB, NBA, $m / z)$ : $1081\left[\mathrm{M}^{+}\right]$. Anal. Calcd. for $\mathrm{C}_{46} \mathrm{H}_{40} \mathrm{Br}_{2} \mathrm{~N}_{4} \mathrm{P}_{2} \mathrm{Pd}_{2}$ : C, 51.00; H, 3.72; N, 5.17. Found: C, 51.22; H, 4.02; N, 5.04.

\section{Single-Crystal X-ray Diffraction Analyses of 4 and 5}

Single crystals of $\mathbf{4}$ and $\mathbf{5}$ suitable for X-ray diffraction analyses were grown by recrystallization from 20:1 diethyl ether/THF and 20:1 $n$-hexane/ $\mathrm{CH}_{2} \mathrm{Cl}_{2}$, respectively. The diffraction data were collected at room temperature on an Enraf-Nonius CAD4 diffractometer equipped with graphite-monochromated Mo $\mathrm{K} \alpha(\lambda=0.71073 \AA)$ radiation. The raw intensity data were converted to structure factor amplitudes and their esd's after correction for scan speed, background, Lorentz, and polarization effects. An empirical absorption correction, based on the azimuthal scan data, was applied to the data. Crystallographic computations were carried out on a Microvax III computer using the NRCC-SDP-VAX structure determination package. ${ }^{14}$

A suitable single crystal of $\mathbf{4}$ was mounted on the top of a glass fiber with glue. Initial lattice parameters were determined from 24 accurately centered reflections with $\theta$ values in the range from 1.37 to $25.00^{\circ}$. Cell constants and other pertinent data were collected and are recorded in Table 1 . Reflection data were collected using the $\theta / 2 \theta$ scan method. Three check reflections were measured every 30 min throughout the data collection and showed no apparent decay. The merging of equivalent and duplicate reflections gave a total of 28570 unique measured data in which 9173 reflections with $\mathrm{I}>2 \sigma(\mathrm{I})$ were considered observed. The structure was first solved by using the heavy-atom method (Patterson synthesis), which revealed the positions of metal atoms. The remaining atoms were found in a series of alternating difference Fourier maps and least-squares refinements. The quantity minimized by the least-squares program was $\omega\left(\left|F_{o}\right|-\left|F_{c}\right|\right)^{2}$, where $\omega$ is the weight of a given operation. The analytical forms of the scattering factor tables for the neutral atoms were used. ${ }^{15}$ The non-hydrogen atoms were refined anisotropically. Hydrogen atoms were included in the structure factor calculations in their expected positions on the basis of idealized bonding geometry but were not refined in least squares. All hydrogens were assigned isotropic thermal parameters 1-2 $\AA^{2}$ larger then the equivalent Biso value of the atom to which they were bonded. The final residuals of this refinement were $\boldsymbol{R}=$ 0.072 and $\boldsymbol{R} \boldsymbol{w}=0.195$.

The procedure for $\mathbf{5}$ was similar to that for $\mathbf{4}$. The final 
residuals of this refinement was $\boldsymbol{R}=0.049$ and $\boldsymbol{R} \boldsymbol{w}=0.131$ for 5 .

CCDC reference numbers: 729691 for 4 and 729692 for $\mathbf{5}$, respectively. Copies of the data can be obtained free of charge, on application to the CCDC, 12 Union Road, Cambridge CB2 IEZ UK (Fax: +44-1-223-336033; E-mail: deposit@ccdc.cam.ac.uk).

\section{ACKNOWLEDGEMENT}

We thank the National Science Council of Taiwan, the Republic of China (NSC96-2113-M-214-001-MY2) for support.

Received January 12, 2009.

\section{REFERENCES}

1. Dobrzynski, E. D.; Angelici, R. J. Inorg. Chem. 1975, 14, 1513.

2. Chin, C. H.; Yeo, S. L.; Loh, Z. H.; Vittal, J. J.; Henderson, W.; Hor, T. S. A. J. Chem. Soc., Dalton Trans. 1988, 3777.

3. Beeby, A.; Bettington, S.; Fairlamb, I. J. S.; Goeta, A. E.; Kapdi, A. R.; Niemela, E. H.; Thompson, A. L. New. J. Chem. 2004, 28, 600.

4. Han, Y.; Hong, Y. T.; Huynh, H. V. J. Organomet. Chem.
2008, 693, 3159.

5. Joshaghani, M.; Daryanavard, M.; Rafiee, E.; Nadri, S. J. Organomet. Chem. 2008, 693, 3135.

6. Yang, W. H.; Lee, C. S.; Pal, S.; Chen, Y. N.; Hwang, W. S.; Lin, J. B.; Wang, J. C. J. Organomet. Chem. 2008, 693, 3729.

7. (a) Lin, Y. C.; Yih, K. H.; Lee, G. H.; Huang, S. L.; Wang, Y. J. Chin. Chem. Soc. 2004, 51, 279. (b) Yih, K. H.; Huang, S. L.; Lee, G. H.; Wang, Y. J. Chin. Chem. Soc. 2004, 51, 493. (c) Yih, K. H.; Lee, G. H.; Wang, Y. J. Chin. Chem. Soc. 2004, 51, 31 .

8. Yih, K. H.; Lee, G. H. J. Chin. Chem. Soc. 2004, 51, 265.

9. Yih, K. H.; Wang, H. F.; Lee, G. H. J. Chin. Chem. Soc. 2007, $54,553$.

10. Yih, K. H.; Lee, G. H. J. Chin. Chem. Soc. 2008, 55, 109.

11. Maitlis, P. M. The Organic Chemistry of Palladium; Academic Press: New York, 1971; Vol. I.

12. Nakatsu, K.; Kinoshita, K.; Kanda, H.; Isobe, K.; Nakamura, A.; Kawaguchi, S. Chem. Lett. 1980, 913.

13. Anderson, T. A.; Barton, R. J.; Robertson, B. E. Acta. Crystallogr. Sect. C 1985, C41, 1171.

14. Gabe, E. J.; Lee, F. L.; Lepage, Y. Crystallographic Computing 3; Shhelldrick, G. M.; Kruger, C.; Goddard, R., Eds.; Clarendon Press: Oxford, England, 1985; p 167.

15. Hamilton, W. C. International Tables for X-ray Crystallography; Reidel: Dordrecht, The Netherlands, 1974; Vol. IV. 